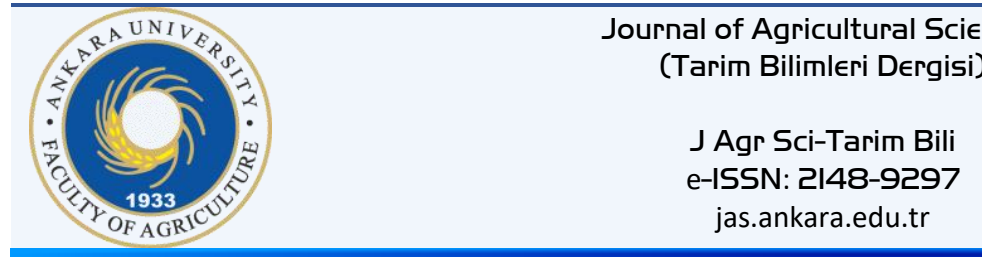

\title{
Effects of Modified Atmosphere Packaging and Methyl Jasmonate Treatments on Fruit Quality and Bioactive Compounds of Apricot Fruit during Cold Storage
}

\author{
Berrak ASLANTÜRK ${ }^{\mathrm{a}} \mathbb{D}$, Ebubekir ALTUNTAS ${ }^{\mathrm{b} *}$ (D) , Burhan OZTURK ${ }^{\mathrm{c} *}$ iD \\ ${ }^{a}$ Çukurova University, Faculty of Agriculture, Department of Agricultural Machinery and Technology Engineering, Adana, TURKEY \\ ${ }^{\boldsymbol{b}}$ Tokat Gaziosmanpaşa University, Faculty of Agriculture, Department of Biosystems Engineering, Tokat, TURKEY \\ ${ }^{c}$ Ordu University, Faculty of Agriculture, Department of Horticulture, Ordu, TURKEY
}

ARTICLE INFO

Research Article

Corresponding Authors: Ebubekir ALTUNTAS, Burhan OZTURK, E-mails: ebubekir.altuntas@gop.edu.tr, burhanozturk55@gmail.com Received: 5 June 2020 / Revised: 23 November 2020 / Accepted: 02 December 2020 / Online: 20 January 2022

\section{ABSTRACT}

The study was carried out to investigate the effects of methyl jasmonate (MeJA) $\left[0.5\right.$ and $\left.1.0 \mathrm{mmol} \mathrm{L}^{-1}\right]$ and modified atmosphere packaging (MAP) treatments on weight loss, respiration rate, firmness, colour, soluble solids content (SSC), titratable acidity, vitamin C, total phenolics, flavonoids and antioxidant capacity (DPPH and FRAP assay) of apricot fruit (Prunus armeniaca) during cold storage. Fruit were stored at $0 \pm 0.5^{\circ} \mathrm{C}$ and $90 \pm 5 \%$ relative humidity (RH) for 20 days, and analysis and measurements were performed at 5-day intervals. At the end of cold storage, the lowest weight loss was determined in fruit stored with the MAP following MeJA1 application. The lowest respiration rates were determined in fruits stored with the MAP following MeJA1 or MeJA2 treatment. The softening of fruit stored without the MAP or MAP was significantly delayed with the MeJA. The fruit stored without the MAP or MAP following MeJA2 treatment had the highest vitamin $\mathrm{C}$ at the end of storage period. MAP treatments had greater total phenolic and total flavonoids and antioxidant capacity than the treatment without MAP regardless of MeJA applications. At the end of storage, the highest total phenolic and antioxidant capacity were determined in fruits stored in the MAP following MeJA2 application. It was concluded that MAP and MeJA2 treatments could be used as an efficient postharvest tool to minimize quality losses throughout the cold storage period.

Keywords: Firmness, Phenolic, Prunus armeniaca, Respiration rate, Weight loss, Vitamin C

(C) Ankara University, Faculty of Agriculture

\section{Introduction}

Apricot is consumed both fresh and dried. It is also served to consumption as processed food like jam, marmalade, juice, nectar, jelly, pulp, frozen fruit and extrusion product (Asma 2007; Jannatizadeh et al. 2008). It is rich in minerals (boron, potassium, calcium, zinc, selenium and iron), provitamin A, vitamin B and vitamin C, sugars, organic acids, carotenoids and phenolic compounds and has a high antioxidant capacity (Sochor et al. 2010; Coşkun et al. 2013). With such rich nutritional attributes, extensive consumption of apricot is recommended against prostration, insomnia and stress and in degradation of body fats, for anaemic and anti-asthmatic effects and to reduce cholesterolaemia (Sochor et al. 2010). Turkey, is the world's leading apricot producer with a production amount of 750000 tons, supports more than $20 \%$ of world total fresh apricot production and more than 56\% of world dried apricot production in 2019 (Anonymous 2020; FAO 2020).

Apricot is a climacteric fruit. Fresh apricots can be stored in cold storages for 2-4 weeks depending on variety to prevent product build-up in markets during the harvest season and resultant quality losses in the phase of marketing (Ezzat et al. 2017). Even with the cold storage of the products, certain quantity of quality losses is evident. Modified atmosphere packaging (MAP) and plant growth regulators (PGRs such as 1-methylcyclopropene, salicylic acid, methyl jasmonate etc.) are commonly used as postharvest tools to minimize such losses (Dong et al. 2002; Moradinezhad \& Jahani 2016; Ezzat et al. 2017). Rather than single use, combined use of MAP and PGRs yields better outcomes in preservation of quality attributes in medlar (Ozturk et al. 2019).

Stored fruit and vegetables with MAP treatments, a special ambient is generated around the product. Such a special ambient reduce oxygen $\left(\mathrm{O}_{2}\right)$ concentration and increase carbondioxide $\left(\mathrm{CO}_{2}\right)$ concentration through respiration process. Decreased $\mathrm{O}_{2}$ and increased $\mathrm{CO}_{2}$ lead to suppression of respiration rate of product. Previous studies reported significant contributions of MAP in the preservation of quality attributes of various fruit species including apricot (Pretel et al. 2000; Ozturk et al. 2019).

Several studies have recently been conducted about the effects of plant growth regulators on postharvest physiology of fruit (Dong et al. 2002; Ezzat et al. 2017; Ozturk et al. 2019). Researchers mostly focused on reduction of quality losses. Consumers 
generally prefer to consume fruit species rich in vitamins, phenolic compounds and antioxidant activity. In this sense, methyl jasmonate (MeJA) was mostly studied in recent researches. MeJA promotes colour development in fruit, retard weight loss and flesh softening during the cold storage and shelf life (Kondo et al. 2001; Rudell et al. 2005; Balbontin et al. 2018). Number of studies about the effects of MeJA treatments on quality attributes of apricot is quite limited (Ezzat et al. 2017).

This study was conducted to investigate the effects of single MeJA +/- MAP treatments on fruit quality attributes and bioactive compounds of 'Precoce de Thyrinthe' apricot cultivar fruit throughout the cold storage period of 20 days.

\section{Material and Methods}

\subsection{Plant materials}

Fruit of 'Precoce de Tyrinthe' apricot (Prunus armeniaca) cultivar were used as the plant material of the study. Fruit were hand-harvested at commercial harvest maturity (15\% SSC) from the Research and Application Orchard of Malatya Apricot Research Institute $\left(38^{\circ} 19^{\prime} \mathrm{N}\right.$ and $\left.38^{\circ} 17^{\prime} \mathrm{E}\right)$. Harvested fruit (18 June 2018) were placed into $5 \mathrm{~kg}$ plastic box $\left(39 \times 29 \times 21 \mathrm{~cm}\right.$, Plastas, Turkey) and transferred to laboratory with frigorific vehicle $\left(10 \pm 1{ }^{\circ} \mathrm{C}\right.$ and $\left.75 \pm 5 \% \mathrm{RH}\right)$ within $6 \mathrm{~h}$. Then fruit with uniform maturity, size and colour and free of damage and defects were selected and defected fruit were discarded.

\subsection{Experimental design and treatments}

Experiments were conducted in randomized plots - factorial experimental design with 3 replications. Initially, fruit were divided into 3 groups. The first group was immersed into only distilled water as control treatment. The second group was immersed into $0.5 \mathrm{mmol} \mathrm{L}^{-1}$ (MeJA1) and the third group into $1.0 \mathrm{mmol} \mathrm{L}{ }^{-1}$ (MeJA2) methyl jasmonate (Sigma-Aldrich, Germany) solutions for $1 \mathrm{~min}$. Fruit were then dried on drying papers under laboratory conditions $\left(21 \pm 1{ }^{\circ} \mathrm{C}\right.$ and $\left.80 \pm 5 \% \mathrm{RH}\right)$ for $1 \mathrm{~h}$. Triton X-100 (0.077\%, Sigma-Aldrich, Germany) was used as a surfactant in MeJA solutions.

For each treatment, fruit were divided into two equal portions. The first group of fruit was placed into $5 \mathrm{~kg}$ plastic boxes in modified atmosphere packaging [Xtend ${ }^{\circledR}(815-A T$ 10/R, StePac, Tefen, Israel)] and the rest was placed into plastic boxes without MAP. For each treatment, a total of 24 boxes were used (12 with MAP (passive) and 12 without MAP). The $\mathrm{O}_{2}$ and $\mathrm{CO}_{2}$ concentrations of MAP were measured with a gas analyser (Abiss, France).

Fruits were initially subjected to pre-cooling with cold air at $4 \pm 0.5{ }^{\circ} \mathrm{C}$ and $90 \pm 5 \% \mathrm{RH}$ for $24 \mathrm{~h}$, then MAP-treated fruit were closed with plastic clips. Fruits were then stored at $0 \pm 0.5{ }^{\circ} \mathrm{C}$ and $90 \pm 5 \% \mathrm{RH}$ for 20 days (d). Measurement and analyses were performed on $5,10,15$ and $20^{\text {th }}$ days of the storage period. For each treatment, 3 boxes were used in each measurement period. Each box represented a replication.

\subsection{Methods}

\subsubsection{Weight loss}

Initial fruit weight (Wi) was determined at the begging of closure (Day 0) with a digital scale ( $\pm 0.01 \mathrm{~g})$ (Radwag, Poland). Then, on day (d) 5, 10, 15 and 20, final fruit weight (Wf) was measured. The weight loss (WL) that occurs in fruit was based on the weight at the beginning of each measurement period and determined as a percentage through the equality given below (Equation 1).

$W L=\frac{W i-W f}{W i} \times 100$

(Equation 1)

\subsubsection{Respiration rate and firmness}

The $2 \mathrm{~L}$ airtight chambers were used to measure respiration rate of fruit. The chambers were fitted with a rubber septum and 5 fruit were sealed in each chamber at $20 \pm 1{ }^{\circ} \mathrm{C}$ temperature and $80 \pm 5 \% \mathrm{RH}$ for $1 \mathrm{~h}$. The chambers were then connected to a gas sensor (Vernier, Oregon, USA) and the amount of $\mathrm{CO}_{2}$ produced by the fruit based on the weight and volume of fruit was considered as the respiration rate. Results were expressed in $\mathrm{mL} \mathrm{CO}_{2} \mathrm{~kg}^{-1} \mathrm{~h}^{-1}$ (Yarılgaç et al. 2019).

Ten fruits from each replication were used for firmness measurements. The measurements were made on two opposite sides of the equatorial part of the fruit through a portable digital durometer (nondestructive device, Agrosta ${ }^{\circledR} 100$ Field, France) with a flat cylindrical penetrating tip $(4.1 \mathrm{~mm})$. The tip of the durometer was slightly and longitudinally pressed into the outer skin of the fruit, and the percentage (\%) value on the screen was recorded. If the value is close to 100, the fruit is considered very firm, and close to 0 indicates that fruit was extremely soft (Ozturk et al. 2019). 


\subsubsection{Colour characteristics}

L*, chroma and hue angles were measured by a colorimeter (Konica-Minolta, CR-400, Japan) in CIE (Commission Internationale de l'Eclairage system) colour system on 10 fruits. Then, the $\mathrm{X}, \mathrm{Y}$ and $\mathrm{Z}$ values were converted into $\mathrm{L}^{*}$, $\mathrm{a}^{*}$ and $\mathrm{b}^{*}$ coordinates using the equations corresponding to illuminant D65 and standard observer $10^{\circ}$. The equation $C^{*}=\left(\mathrm{a}^{* 2}+\mathrm{b}^{* 2}\right)^{1 / 2}$ was used for chroma and $h^{\circ}=\tan ^{-1} \mathrm{~b}^{*} / \mathrm{a}^{*}$ for hue angle.

\subsubsection{Soluble solids content, titratable acidity and vitamin $C$}

Ten fruits taken from each replication were first washed with distilled water. The fruit were chopped with a stainless-steel knife and cut into parts and homogenized by a blender (Model No. Promix HR2653 Philips, Turkey). Then the homogenate was filtered through a cheesecloth, and the juice was obtained. Soluble solids content (SSC) was measured with a portable digital refractometer (Atago PAL-1, USA) and expressed in \%. For titratable acidity measurement, $10 \mathrm{~mL}$ juice was taken, and $10 \mathrm{~mL}$ distilled water was added on. Then $0.1 \mathrm{~N} \mathrm{NaOH}$ (sodium hydroxide) was added until the $\mathrm{pH}$ of the solution reach to 8.2 . Based on the amount of $\mathrm{NaOH}$ consumed in titration, titratable acidity was determined and expressed as $\mathrm{g}_{\text {malic }}$ acid $\mathrm{kg}^{-1}$.

For vitamin $\mathrm{C}$ measurement, $0.5 \mathrm{~mL}$ juice was taken, and $5 \mathrm{~mL}$ of $0.5 \%$ oxalic acid was added on it. The ascorbic acid test strip (Catalog no: 116981, Merck, Germany) was then taken from a collapsible sealed gas-tight tube. Reflectometer (Merck RQflex plus 10) was started. The test strip was plunged into the solution for 2 seconds, then removed from the solution. It was then held for 8 seconds, and reading was done at the end of the $15^{\text {th }}$ second. Results were expressed as mg kg-1 $(\mathrm{Ozturk}$ et al. 2019).

\subsubsection{Total phenolics, total flavonoids and antioxidant capacity}

During each measurement period, 10 fruit were taken from each replication of each treatment. The fruit were washed with distilled water and sliced with a stainless-steel knife. Later, the fruit pulp was crumbled by a blender, and homogenized. About $30 \mathrm{~mL}$ of homogenate was taken and placed into a $50 \mathrm{~mL}$ falcon tube. The tubes were kept at $-20{ }^{\circ} \mathrm{C}$ until the analyses.

Before the analyses, the frozen samples were dissolved under room temperature $\left(21^{\circ} \mathrm{C}\right)$. Pulp and juice were separated from each other by a centrifuge at $12000 \times \mathrm{g}$ at $4{ }^{\circ} \mathrm{C}$ for $35 \mathrm{~min}$. The resultant filtrate was used to determine the total phenolics, total flavonoids and antioxidant activity.

Spectrophotometric measurements for bioactive compounds were performed in a UV-Vis spectrophotometer (Shimadzu, Kyoto, Japan). Total phenolics were measured according to the method of Beyhan et al. (2010) and was expressed as $\mathrm{g} \mathrm{kg}^{-1}$ GAE (gallic acid equivalent) fresh weight (fw). Total flavonoids were measured according to the method of Zhishen et al. (1999) and was expressed as $\mathrm{g} \mathrm{kg}^{-1} \mathrm{QE}$ (quercetin equivalent) fw.

The antioxidant capacity of apricot fruit was determined according to two different procedures of 1.1-diphenyl-2-picrylhydrazil (DPPH) (Blois 1958) and Ferric Ions ( $\mathrm{Fe}^{+3}$ ) Reducing Antioxidant Power (FRAP) (Benzie and Strain 1996), and the results were expressed as $\mathrm{mmol} \mathrm{kg}{ }^{-1}$ trolox equivalent (TE) fw.

\subsection{Statistical analysis}

Whether the data was normally distributed or not, it was checked by Kolmogrov-Smirnov Test. Homogeneity control of the group/subgroup variances was confirmed by Levene's test. After the variance analysis of the data, Tukey's multiplecomparison test was used to check whether there were significant differences $(\mathrm{P}<0.05)$ between the treatments or not. The statistical analyses were performed by using SAS software (SAS 9.1 version, USA).

\section{Results}

\subsection{Weight loss}

Weight losses were observed in apricot fruit throughout the cold storage. Considering the general average, MAP treatment significantly reduced weight loss, reducing the weight loss from $2.3 \%$ in non-MAP fruits to $0.7 \%$ (Figure 1 B). Effects of MeJA treatments varied with whether the fruit were treated with MAP or not. In 15 and $20^{\text {th }} \mathrm{d}$ of storage period, MeJA+MAP treated fruit yielded significantly lower weight losses than controls. On day 20, under MAP treatment, while weight loss in control treatment was $1.26 \%$, it was found as $0.73 \%$ and $0.96 \%$ in MeJA1 and MeJA2 applications, respectively. However, significantly greater weight loss was observed in single MeJA-treated fruit than controls. Weight loss increased to $2.5 \%$ in control, 3.38\% in MeJA2 and 3.59 in MeJA application at the end of the 20-day storage period (Figure 1 A). 

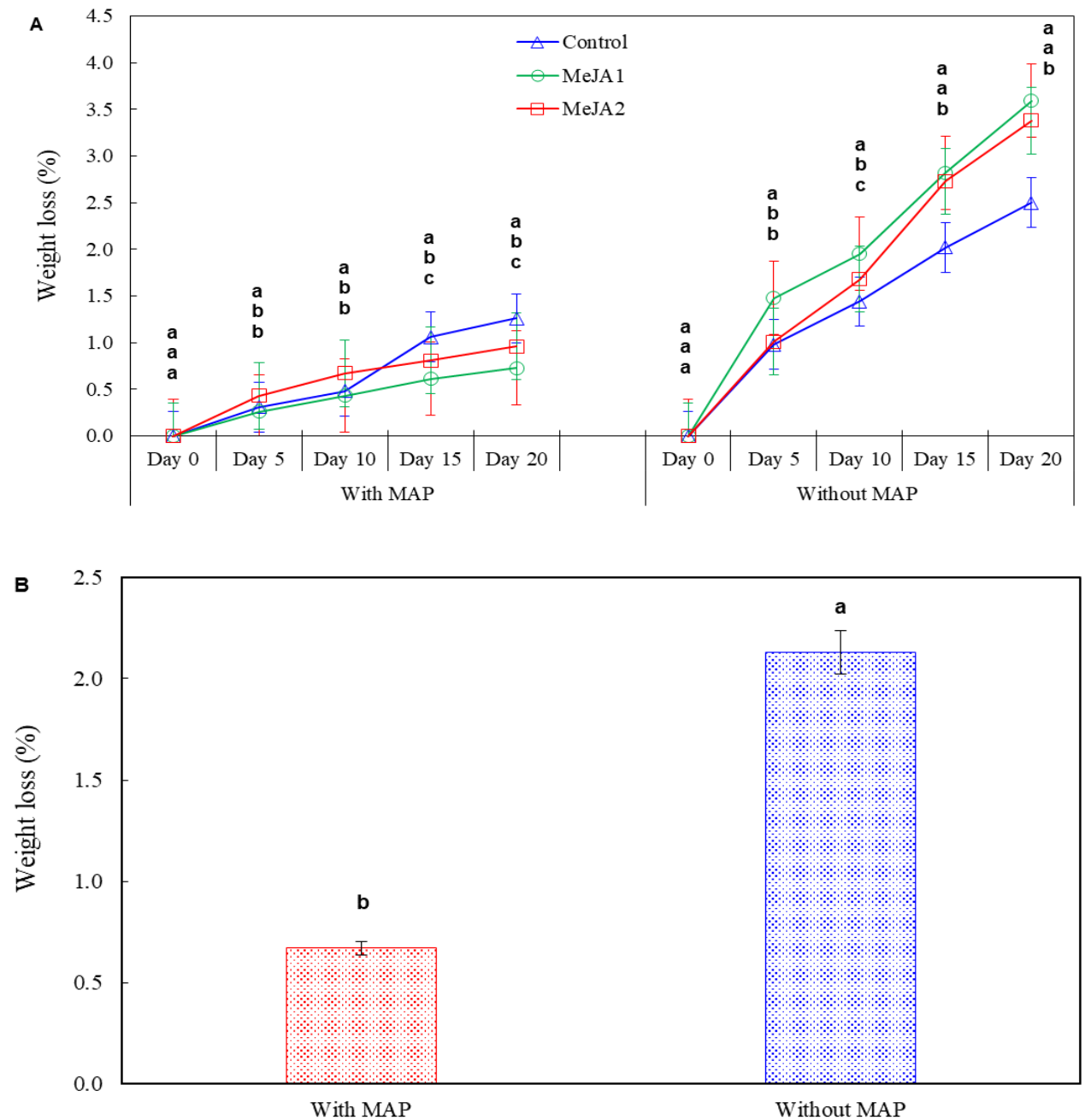

Figure 1- Effects of MeJA treatments (A) and MAP (B) on weight loss of fruit during the cold storage at $0 \pm 0.5{ }^{\circ} \mathrm{C}$ and $90 \pm 5 \%$ RH for 20 days. The means indicated with the same letter vertically in periods, and above the bars were not significant according to Tukey's test at $\mathbf{P}<0.05$

\subsection{Respiration rate and firmness}

Throughout the storage period, changes of $\mathrm{O}_{2}$ and $\mathrm{CO}_{2}$ concentrations inside MAPs were shown in Figure 2. Considering the general averages, it was observed that MAP-treated fruit had significantly lower respiration rates $\left(35.3 \mathrm{~mL} \mathrm{CO}_{2} \mathrm{~kg}^{-1} \mathrm{~h}^{-1}\right)$ than the untreated fruit $\left(48.0 \mathrm{~mL} \mathrm{CO} \mathrm{kg}^{-1} \mathrm{~h}^{-1}\right)$. The flesh firmness was $62.0 \%$ in fruits with the MAP and 55.5\% in those without the MAP, and the difference between two treatments was statistically significant (Figure 3A). Considering the MAP $\mathrm{x}$ MeJA interactions, with or without the MAP, both MeJA treatment had lower respiration rates than control at all the dates of measurement (except for 5 and $15^{\text {th }} \mathrm{d}$ of MeJA1). After 20 days of storage period, respiration rates were decreased from 41.1 to 33.4, 26.8 and $26.6 \mathrm{~mL} \mathrm{CO}_{2} \mathrm{~kg}^{-1} \mathrm{~h}^{-1}$, respectively, in control, MeJA1 and MeJA2 treatments. Without the MAP, respiration rates at the end of storage period were 51.9, 46.7 and $36.4 \mathrm{~mL} \mathrm{CO}_{2} \mathrm{~kg}^{-1} \mathrm{~h}^{-}$in control, MeJA1 and MeJA2 treatments, respectively (Figure 3B). In with and without $\mathrm{MeJA}$ treatments, the $\mathrm{O}_{2}$ in the MAP atmosphere similarly decreased and $\mathrm{CO}_{2}$ content similarly increased during the storage process. A significant relationship between the respiratory rate of the products and the concentration of $\mathrm{O}_{2}$ and $\mathrm{CO}_{2}$ in the MAP atmosphere was not detected (Figure 2A, B, C). 

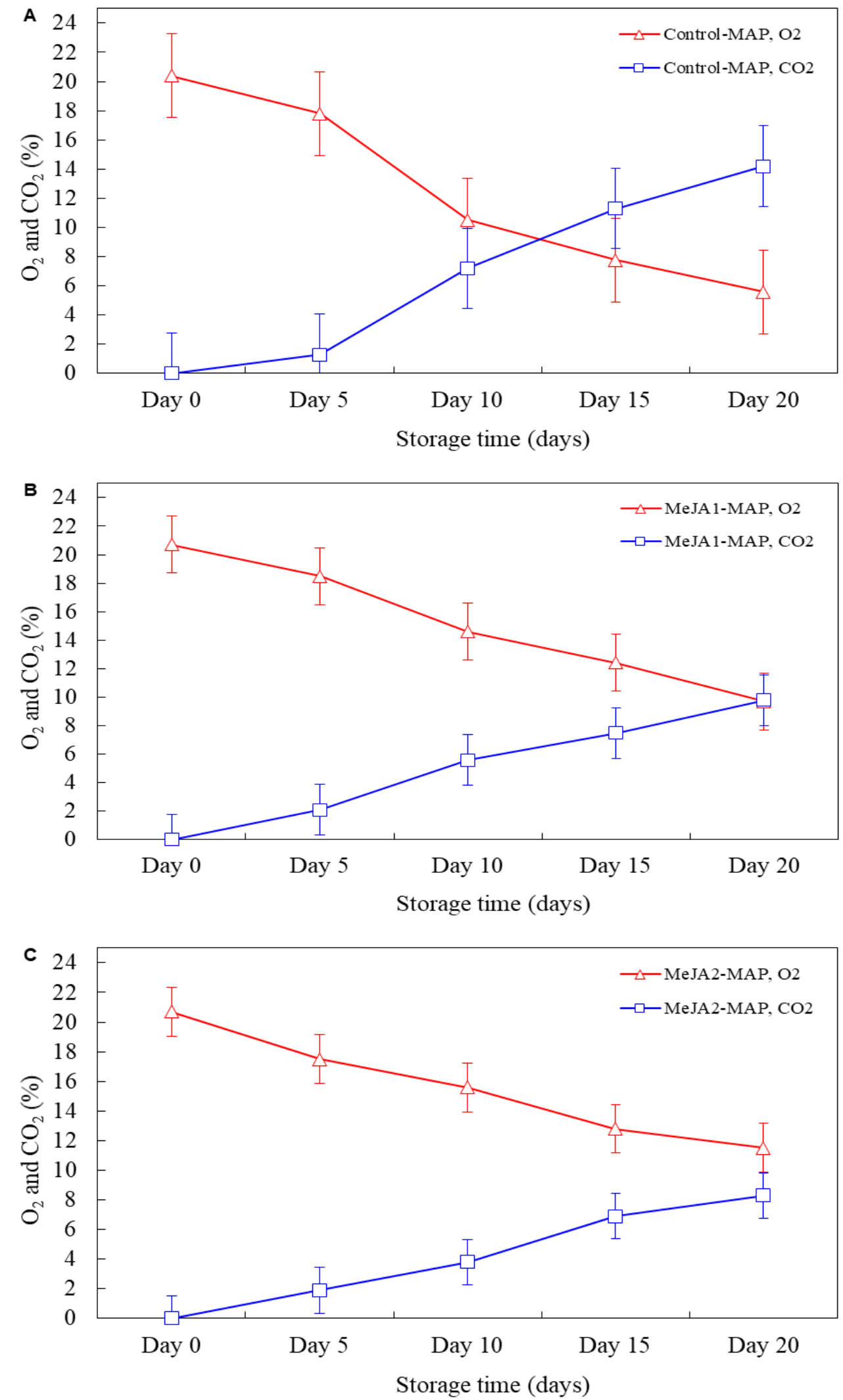

Figure 2- Changes of $\mathrm{CO}_{2}$ and $\mathrm{O}_{2}$ concentrations of control (A), MeJA1 (B) and MeJA2 (C) treatments inside MAP during the storage at $0 \pm 0.5{ }^{\circ} \mathrm{C}$ and $90 \pm 5 \%$ RH for 20 days 

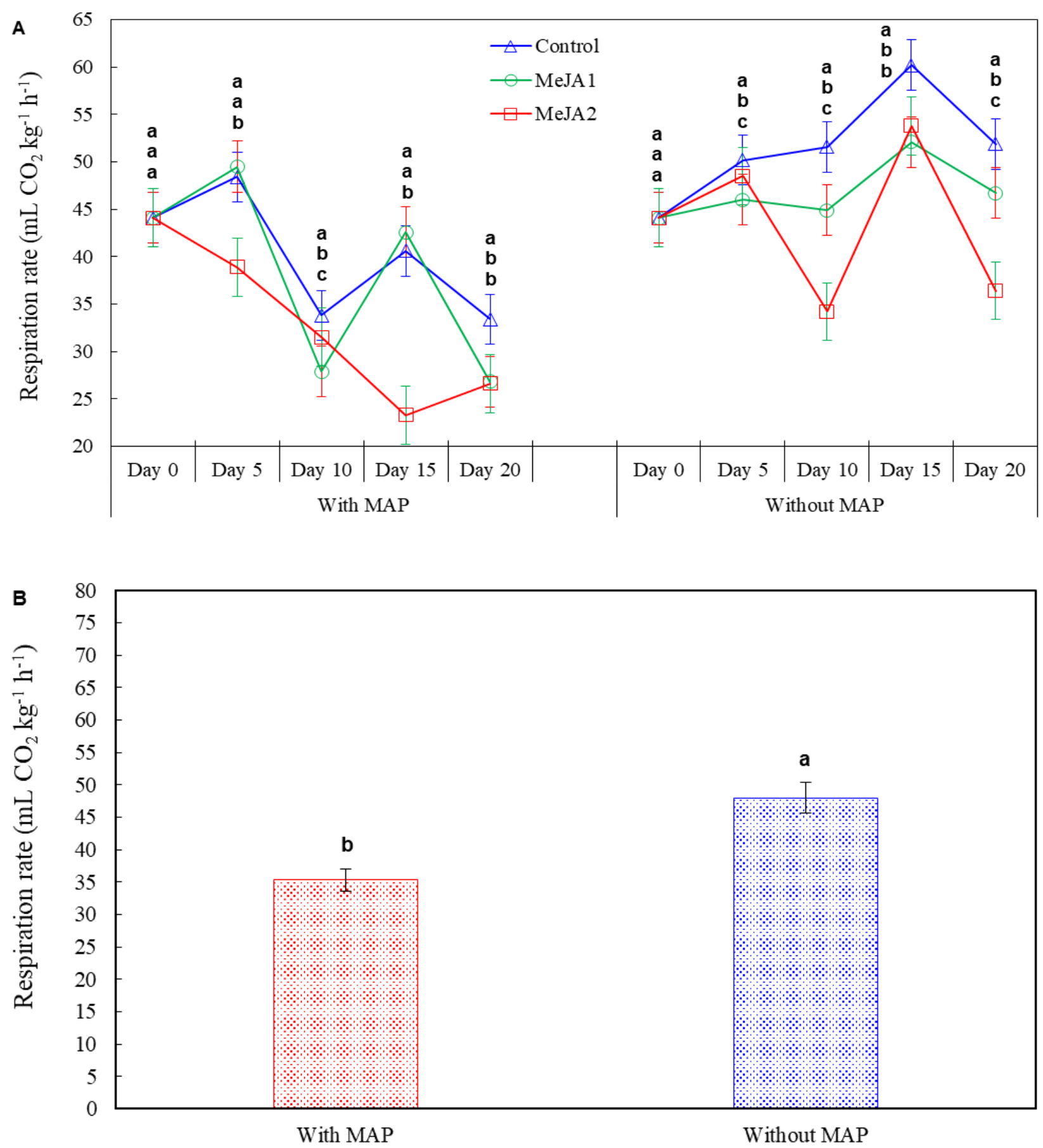

Figure 3- Effects of MeJA treatments $(\mathrm{A})$ and MAP $(\mathrm{B})$ on respiration rate of apricot fruit during the cold storage at $0 \pm 0.5$ ${ }^{\circ} \mathrm{C}$ and $90 \pm 5 \%$ RH for 20 days. The means indicated with the same letter vertically in periods, and above the bars were not significant according to Tukey's test at $\mathbf{P}<0.05$

Regardless of MAP treatments, both MeJA treatment had significantly greater firmness than the control at all the dates of measurement. At the end of storage with the MAP, firmness was 55.4, 62.2 and 61.6\% in control, MeJA1 and MeJA2 treatments. Without the MAP, while the firmness of controls was $47.7 \%$, the firmness values of fruit treated with MeJA1 and MeJA were $58.8 \%$ and $53.4 \%$, respectively (Figure 4A-B). 

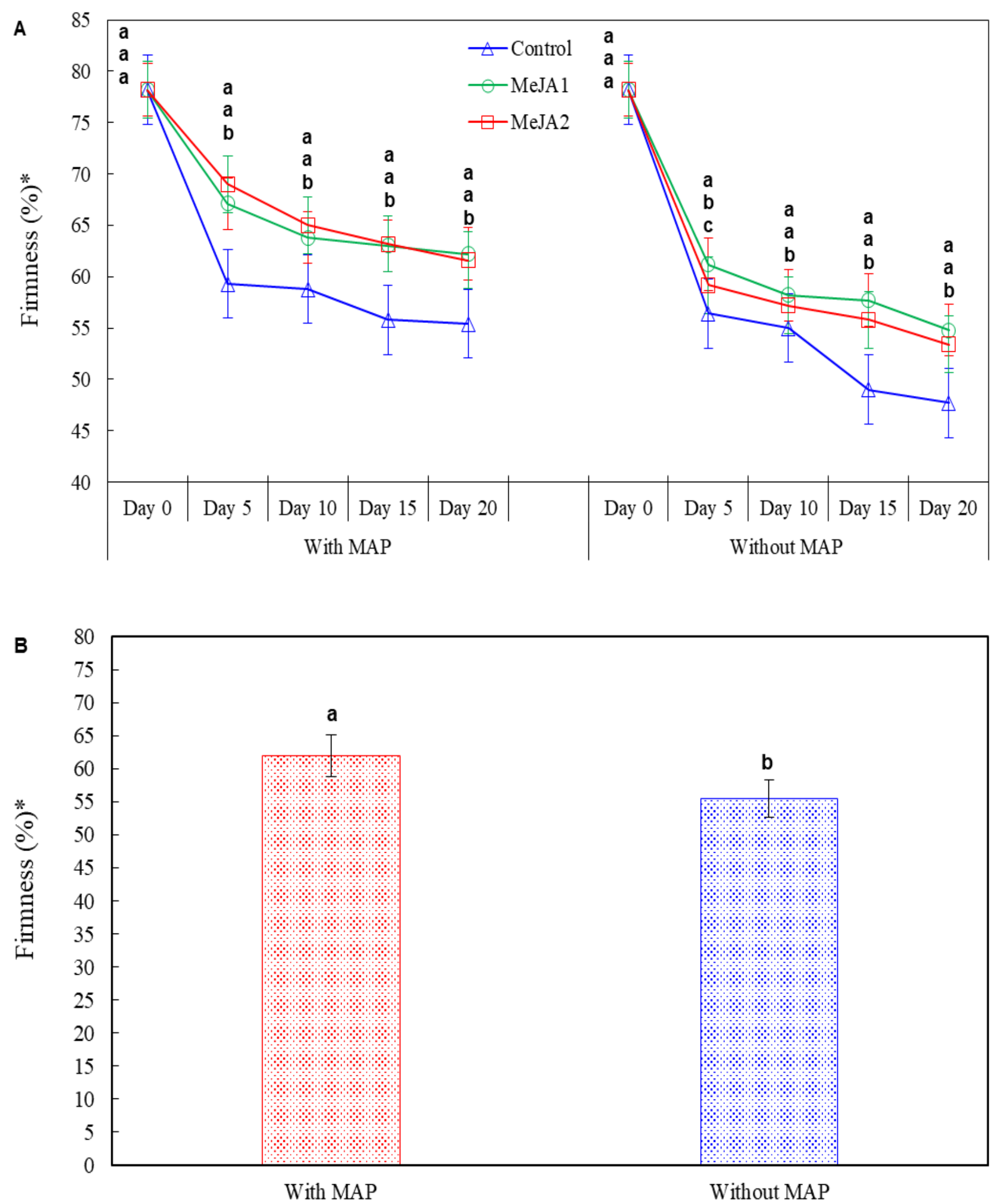

Figure 4- Effects of MeJA treatments (A) and MAP (B) on firmness of apricot fruit during the cold storage at $0 \pm 0.5{ }^{\circ} \mathrm{C}$ and $90 \pm 5 \%$ RH for 20 days. * The scale ranges from 0 to 100 for very soft to very firm surfaces. The means indicated with the same letter vertically in periods, and above the bars were not significant according to Tukey's test at $P<0.05$

\subsection{Colour characteristics}

Considering the general averages for colour parameters, it was observed that MAP-treated fruit had significantly lower hue angle (82.6), $\mathrm{L}^{*}(64.2)$ and chroma values (52.1) than the untreated fruit which had hue angle of 84.7, 67.8 of $\mathrm{L}$ and 53.8 of 
chroma values. Considering the MAP x MeJA interactions, with the MAP, the effects of MeJA treatments on L* values varied depending on the measurement dates. On the $20^{\text {th }}$ day of storage period, both MeJA treatments had significantly greater L* values than the controls. At the end of the storage period, while $\mathrm{L}^{*}$ value of controls was 62.5 , those of MeJA1 and MeJA2 treatments was 66.0 and 65.5, respectively. Without MAP, no significant change was observed in the $\mathrm{L}^{*}$ value due to MeJA, except for $15^{\text {th }} \mathrm{d}$ of storage period. During storage with the MAP, MeJA did not cause any significant change in chroma values of fruit colour. Without the MAP, the effect of MeJA on chroma differed according to storage period. At the end of storage period of 20 days, the chroma value, which was 51.8 in the controls, significantly increased to 53.7 in the MeJA2 treatment. Although there were exceptions depending on the storage periods, generally, there was no change in the hue values due to MeJA treatment with or without MAP (Table 1).

Table 1- Effects of MAP and MeJA treatments on $\mathrm{L}^{*}$, chroma and hue angle of apricot fruit during the cold storage at $0 \pm 0.5{ }^{\circ} \mathrm{C}$ and $90 \pm 5 \%$ RH for 20 days

\begin{tabular}{|c|c|c|c|c|c|c|c|}
\hline \multirow{2}{*}{ MAP } & \multirow{2}{*}{ Treatments } & \multicolumn{5}{|c|}{$L^{*}$} & \multirow{2}{*}{ Mean } \\
\hline & & Day 0 & Day 5 & Day 10 & Day 15 & Day 20 & \\
\hline \multirow{3}{*}{ With MAP } & Control & 69.1 & $66.7 \mathrm{a}$ & $61.9 \mathrm{~b}$ & $64.9 \mathrm{a}$ & $62.5 \mathrm{~b}$ & \multirow{3}{*}{$64.2 \mathrm{l}$} \\
\hline & MeJA1 & 69.1 & $62.9 \mathrm{~b}$ & $66.6 \mathrm{a}$ & $59.6 \mathrm{~b}$ & $66.0 \mathrm{a}$ & \\
\hline & MeJA2 & 69.1 & $65.4 \mathrm{a}$ & $67.8 \mathrm{a}$ & $60.9 \mathrm{~b}$ & $65.5 \mathrm{a}$ & \\
\hline \multirow{5}{*}{ Without MAP } & Control & 69.1 & $68.7^{\mathrm{ns}}$ & $68.7^{\mathrm{ns}}$ & $68.1 \mathrm{a}$ & $68.1^{\mathrm{ns}}$ & \multirow{3}{*}{67.8} \\
\hline & MeJA1 & 69.1 & $67.9^{\mathrm{ns}}$ & $68.7^{\text {ns }}$ & $65.9 \mathrm{~b}$ & $67.2^{\mathrm{ns}}$ & \\
\hline & MeJA2 & 69.1 & $67.8^{\mathrm{ns}}$ & $68.6^{\mathrm{ns}}$ & $65.8 \mathrm{~b}$ & $68.1^{\mathrm{ns}}$ & \\
\hline & & \multicolumn{5}{|c|}{ Chroma } & \\
\hline & & Day 0 & Day 5 & Day 10 & Day 15 & Day 20 & \\
\hline \multirow{3}{*}{ With MAP } & Control & 56.0 & $52.2^{\mathrm{ns}}$ & $50.8^{\mathrm{ns}}$ & $50.6^{\mathrm{ns}}$ & $50.2^{\mathrm{ns}}$ & \multirow{3}{*}{52.11} \\
\hline & MeJA1 & 56.0 & $54.1^{\mathrm{ns}}$ & $52.1^{\mathrm{ns}}$ & $52.8^{\mathrm{ns}}$ & $50.9^{\mathrm{ns}}$ & \\
\hline & MeJA2 & 56.0 & $53.3^{\mathrm{ns}}$ & $53.5^{\mathrm{ns}}$ & $52.8^{\mathrm{ns}}$ & $51.9^{\mathrm{ns}}$ & \\
\hline \multirow{5}{*}{ Without MAP } & Control & 56.0 & $53.5 \mathrm{~b}$ & $55.3^{\mathrm{ns}}$ & $52.2 \mathrm{~b}$ & $51.8 \mathrm{~b}$ & \multirow{3}{*}{53.8} \\
\hline & MeJA1 & 56.0 & $55.1 \mathrm{a}$ & $53.2^{\mathrm{ns}}$ & $54.6 \mathrm{a}$ & $52.7 \mathrm{~b}$ & \\
\hline & MeJA2 & 56.0 & $54.7 \mathrm{a}$ & $53.9^{\mathrm{ns}}$ & $54.3 \mathrm{a}$ & $53.7 \mathrm{a}$ & \\
\hline & & \multicolumn{5}{|c|}{ Hue angle } & \\
\hline & & Day 0 & Day 5 & Day 10 & Day 15 & Day 20 & \\
\hline \multirow{3}{*}{ With MAP } & Control & 87.6 & $82.4 \mathrm{~b}$ & $82.5^{\mathrm{ns}}$ & $82.2^{\mathrm{ns}}$ & $82.3^{\mathrm{ns}}$ & \multirow{3}{*}{$82.6 \mathrm{~b}$} \\
\hline & MeJA1 & 87.6 & $83.1 \mathrm{a}$ & $83.2^{\mathrm{ns}}$ & $81.8^{\mathrm{ns}}$ & $82.5^{\mathrm{ns}}$ & \\
\hline & MeJA2 & 87.6 & $83.8 \mathrm{a}$ & $83.7^{\mathrm{ns}}$ & $81.6^{\mathrm{ns}}$ & $82.6^{\mathrm{ns}}$ & \\
\hline \multirow{3}{*}{ Without MAP } & Control & 87.6 & $84.5^{\mathrm{ns}}$ & $86.7 \mathrm{a}$ & $84.1^{\mathrm{ns}}$ & $84.0^{\mathrm{ns}}$ & \multirow{3}{*}{$84.7 \mathrm{a}$} \\
\hline & MeJA1 & 87.6 & $83.6^{\mathrm{ns}}$ & $84.8 \mathrm{~b}$ & $83.7^{\mathrm{ns}}$ & $83.7^{\mathrm{ns}}$ & \\
\hline & MeJA2 & 87.6 & $85.2^{\mathrm{ns}}$ & $87.4 \mathrm{a}$ & $84.3^{\mathrm{ns}}$ & $84.1^{\mathrm{ns}}$ & \\
\hline
\end{tabular}

ns: non-significant. The differences between the means indicated with the same lower-case letters in the same column were not significant according to Tukey's test

\subsection{Soluble solids content (SSC), titratable acidity and vitamin C}

Based on general mean values, it was observed that MAP-treated fruit had significantly higher SSC and vitamin C content and lower acidity values than the untreated fruit. Considering the MAP x MeJA interactions, it was observed that MeJA2 treatment with the MAP yielded significantly lower SSC than controls and MeJA1-treated fruit on day 15 and 20. At the end of storage period, SSC values in controls, MeJA1 and MeJA2-treated fruit were 18.5\%, 18.2\% and 17.9\%, respectively. MeJA treatments without the MAP did not cause any significant change in SSC of fruit, except for $10^{\text {th }}$ day of storage period. During the storage with the MAP, except for $20^{\text {th }}$ day of storage, no significant change in titratable acidity between control and MeJA treatments

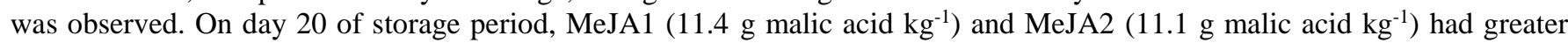
acidity content than controls ( $10.5 \mathrm{~g}$ malic acid $\left.\mathrm{kg}^{-1}\right)$. MeJA treatments without the MAP did not cause any significant change in acidity content of fruit, except for $5^{\text {th }}$ day of storage. While the effect of only MeJA1 treatment was significant with the MAP treatment, both MeJA treatment caused a significant increase in vitamin C content without MAP. On day 20 of storage with the MAP, while the vitamin $\mathrm{C}$ was $76.6 \mathrm{mg} \mathrm{kg}^{-1}$ in the control, it was $83.0 \mathrm{mg} \mathrm{kg}^{-1}$ in the MeJA2 treatment (Table 2). 
Table 2- Effects of MAP and MeJA treatments on soluble solids content (SSC), titratable acidity and vitamin C content of apricot fruit during the cold storage at $0 \pm 0.5^{\circ} \mathrm{C}$ and $90 \pm 5 \% \mathrm{RH}$ for 20 days

\begin{tabular}{|c|c|c|c|c|c|c|c|}
\hline \multirow{2}{*}{ MAP } & \multirow{2}{*}{ Treatments } & \multicolumn{5}{|c|}{$S S C(\%)$} & \multirow{2}{*}{ Mean } \\
\hline & & Day 0 & Day 5 & Day 10 & Day 15 & Day 20 & \\
\hline \multirow{3}{*}{ With MAP } & Control & 15.5 & $16.9^{\mathrm{ns}}$ & $17.3^{\mathrm{ns}}$ & $17.3 \mathrm{a}$ & $18.5 \mathrm{a}$ & \multirow{3}{*}{$17.4 \mathrm{a}$} \\
\hline & MeJA1 & 15.5 & $17.4^{\mathrm{ns}}$ & $17.5^{\mathrm{ns}}$ & $17.6 \mathrm{a}$ & $18.2 \mathrm{a}$ & \\
\hline & MeJA2 & 15.5 & $16.5^{\mathrm{ns}}$ & $16.6^{\mathrm{ns}}$ & $16.9 \mathrm{~b}$ & $17.9 \mathrm{~b}$ & \\
\hline \multirow{5}{*}{ Without MAP } & Control & 15.5 & $16.3^{\mathrm{ns}}$ & $16.3 \mathrm{a}$ & $16.4^{\mathrm{ns}}$ & $16.6^{\mathrm{ns}}$ & \multirow{3}{*}{$16.3 \mathrm{~b}$} \\
\hline & MeJA1 & 15.5 & $15.7^{\mathrm{ns}}$ & $15.9 \mathrm{~b}$ & $16.4^{\mathrm{ns}}$ & $17.1^{\mathrm{ns}}$ & \\
\hline & MeJA2 & 15.5 & $16.1^{\mathrm{ns}}$ & $16.2 \mathrm{a}$ & $16.3^{\mathrm{ns}}$ & $16.3^{\mathrm{ns}}$ & \\
\hline & & \multicolumn{5}{|c|}{ Titratable acidity $\left(\mathrm{g}\right.$ malic acid $\left.\mathrm{kg}^{-1}\right)$} & \\
\hline & & Day 0 & Day 5 & Day 10 & Day 15 & Day 20 & \\
\hline \multirow{3}{*}{ With MAP } & Control & 15.1 & $12.2^{\mathrm{ns}}$ & $11.9^{\mathrm{ns}}$ & $11.4^{\mathrm{ns}}$ & $10.5 \mathrm{~b}$ & \multirow{3}{*}{$11.9 \mathrm{~b}$} \\
\hline & MeJA1 & 15.1 & $12.5^{\mathrm{ns}}$ & $12.4^{\mathrm{ns}}$ & $12.0^{\mathrm{ns}}$ & $11.4 \mathrm{a}$ & \\
\hline & MeJA2 & 15.1 & $12.7^{\mathrm{ns}}$ & $12.3^{\mathrm{ns}}$ & $12.2^{\mathrm{ns}}$ & $11.1 \mathrm{a}$ & \\
\hline \multirow{5}{*}{ Without MAP } & Control & 15.1 & $13.7 \mathrm{~b}$ & $13.1^{\mathrm{ns}}$ & $13.0^{\mathrm{ns}}$ & $12.8^{\mathrm{ns}}$ & \multirow{3}{*}{$13.4 \mathrm{a}$} \\
\hline & MeJA1 & 15.1 & $13.8 \mathrm{~b}$ & $13.7^{\mathrm{ns}}$ & $13.4^{\mathrm{ns}}$ & $12.7^{\mathrm{ns}}$ & \\
\hline & MeJA2 & 15.1 & $14.5 \mathrm{a}$ & $13.7^{\mathrm{ns}}$ & $13.0^{\mathrm{ns}}$ & $12.9^{\mathrm{ns}}$ & \\
\hline & & \multicolumn{5}{|c|}{ Vitamin $\mathrm{C}\left(\mathrm{mg} \mathrm{kg}^{-1}\right)$} & \\
\hline & & Day 0 & Day 5 & Day 10 & Day 15 & Day 20 & \\
\hline \multirow{3}{*}{ With MAP } & Control & 98.3 & $89.7 \mathrm{~b}$ & $87.0^{\mathrm{ns}}$ & $79.7 \mathrm{~b}$ & $76.0 \mathrm{~b}$ & \multirow{3}{*}{$85.8 \mathrm{a}$} \\
\hline & MeJA1 & 98.3 & $90.3 \mathrm{~b}$ & $88.3^{\text {ns }}$ & $81.0 \mathrm{~b}$ & $73.3 \mathrm{~b}$ & \\
\hline & MeJA2 & 98.3 & $94.0 \mathrm{a}$ & $89.0^{\mathrm{ns}}$ & $88.0 \mathrm{a}$ & $83.0 \mathrm{a}$ & \\
\hline \multirow{3}{*}{ Without MAP } & Control & 98.3 & $60.3 \mathrm{~b}$ & $56.3 \mathrm{~b}$ & $42.7 \mathrm{~b}$ & $41.0 \mathrm{~b}$ & \multirow{3}{*}{$54.9 \mathrm{~b}$} \\
\hline & MeJA1 & 98.3 & $61.7 \mathrm{~b}$ & $60.3 \mathrm{a}$ & $57.3 \mathrm{a}$ & $49.7 \mathrm{a}$ & \\
\hline & MeJA2 & 98.3 & $66.3 \mathrm{a}$ & $60.3 \mathrm{a}$ & $52.3 \mathrm{a}$ & $50.3 \mathrm{a}$ & \\
\hline
\end{tabular}

ns: non-significant. The differences between the means indicated with the same lower-case letters in the same column were not significant according to Tukey's test

\subsection{Total phenolics, total flavonoids and antioxidant capacity}

Considering the general means, it was observed that MAP-treated fruit had significantly greater total phenolics (36.9 g GAE $\left.\mathrm{kg}^{-1}\right)$, total flavonoids $\left(0.99 \mathrm{~g} \mathrm{QE} \mathrm{kg}^{-1}\right)$ and antioxidant capacity $\left(5.24 \mathrm{mmol} \mathrm{TE} \mathrm{kg}{ }^{-1}\right.$ in DPPH and $15.6 \mathrm{mmol} \mathrm{TE} \mathrm{kg}{ }^{-1}$ in FRAP assays) than the untreated fruit. MAP x MeJA interactions were also found to be significant for bioactive compounds (Table 3).

Considering the measurements data in the last measurement period of the cold storage, it was observed that MeJA+MAP treatments yielded significantly greater total phenolics and antioxidant capacity than controls. Similarly, MeJA2 treatments without MAP had significantly greater total phenolics and antioxidant capacity than controls and MeJA1-treated fruit. However, MeJA2 + MAP treatments and MeJA treatments without MAP yielded significantly lower total flavonoids than controls (Table 3). During the storage period, total phenolics of the MeJA2-treated fruit was higher than that of the controls at all measurement dates. On day 20 of storage period with MAP, while the amount total phenolics was $28.0 \mathrm{~g} \mathrm{GAE} \mathrm{kg}^{-1}$, it was measured as $36.4 \mathrm{~g} \mathrm{GAE} \mathrm{kg}^{-1}$ in MeJA treatment. The effect of MeJA treatments on total phenolics differed depending on storage periods. At the end of storage with the MAP, while control fruit had total flavonoids of $0.99 \mathrm{~g} \mathrm{QE} \mathrm{kg}^{-1}$, MeJA2 treated fruit had total flavonoids of $0.95 \mathrm{~g} \mathrm{QE} \mathrm{kg}^{-1}$. At the end of storage without the MAP, while control fruit had total flavonoids of $0.91 \mathrm{~g} \mathrm{QE} \mathrm{kg}^{-1}$, MeJA1 and MeJA2-treated fruit had total flavonoids of 0.93 and $0.76 \mathrm{~g} \mathrm{QE} \mathrm{kg}^{-1}$, respectively. Although the effect of MeJA treatments on antioxidant capacity varied depending on the storage period, there were slight increases caused by MeJA treatments (Table 3 ). 
Table 3- Effects of MAP and MeJA treatments on total phenolics, total flavonoids and antioxidant activity of apricot fruit during the cold storage at $0 \pm 0.5{ }^{\circ} \mathrm{C}$ and $90 \pm 5 \% \mathrm{RH}$ for 20 days

\begin{tabular}{|c|c|c|c|c|c|c|c|}
\hline \multirow{2}{*}{$M A P$} & \multirow{2}{*}{ Treatments } & \multicolumn{5}{|c|}{ Total phenolics $\left(\mathrm{g} G A E \mathrm{~kg}^{-1}\right)$} & \multirow{2}{*}{ Mean } \\
\hline & & Day 0 & Day 5 & Day 10 & Day 15 & Day 20 & \\
\hline \multirow{3}{*}{ With MAP } & Control & 19.9 & $31.2 \mathrm{c}$ & $35.9 \mathrm{~b}$ & $29.0 \mathrm{~b}$ & $28.0 \mathrm{~b}$ & \multirow{3}{*}{$36.9 \mathrm{a}$} \\
\hline & MeJA1 & 19.9 & $36.0 \mathrm{~b}$ & $39.8 \mathrm{~b}$ & $32.3 \mathrm{~b}$ & $34.7 \mathrm{a}$ & \\
\hline & MeJA2 & 19.9 & $39.5 \mathrm{a}$ & $61.8 \mathrm{a}$ & $38.7 \mathrm{a}$ & $36.4 \mathrm{a}$ & \\
\hline \multirow{5}{*}{ Without MAP } & Control & 19.9 & $20.2 \mathrm{~b}$ & $22.38 \mathrm{~b}$ & $30.1 \mathrm{~b}$ & $24.1 \mathrm{~b}$ & \multirow{3}{*}{$26.2 \mathrm{~b}$} \\
\hline & MeJA1 & 19.9 & $26.3 \mathrm{a}$ & $22.90 \mathrm{~b}$ & $27.3 \mathrm{~b}$ & $22.0 \mathrm{~b}$ & \\
\hline & MeJA2 & 19.9 & $28.8 \mathrm{a}$ & $24.28 \mathrm{a}$ & $38.6 \mathrm{a}$ & $27.4 \mathrm{a}$ & \\
\hline & & \multicolumn{5}{|c|}{ Total flavonoids $\left(\mathrm{g} \mathrm{QE} \mathrm{kg}^{-1}\right)$} & \\
\hline & & Day 0 & Day 5 & Day 10 & Day 15 & Day 20 & \\
\hline \multirow{3}{*}{ With MAP } & Control & 0.56 & $0.88 \mathrm{~b}$ & $1.18 \mathrm{a}$ & $0.85 \mathrm{~b}$ & $0.99 \mathrm{a}$ & \multirow{3}{*}{$0.99 \mathrm{a}$} \\
\hline & MeJA1 & 0.56 & $0.91 \mathrm{~b}$ & $1.09 \mathrm{~b}$ & $0.84 \mathrm{~b}$ & $1.01 \mathrm{a}$ & \\
\hline & MeJA2 & 0.56 & $1.04 \mathrm{a}$ & $1.21 \mathrm{a}$ & $0.98 \mathrm{a}$ & $0.95 \mathrm{~b}$ & \\
\hline \multirow{5}{*}{ Without MAP } & Control & 0.56 & $0.65 \mathrm{~b}$ & $0.63^{\mathrm{ns}}$ & $0.79 \mathrm{~b}$ & $0.91 \mathrm{a}$ & \multirow{3}{*}{$0.76 \mathrm{~b}$} \\
\hline & MeJA1 & 0.56 & $0.71 \mathrm{~b}$ & $0.68^{\mathrm{ns}}$ & $0.87 \mathrm{a}$ & $0.73 \mathrm{~b}$ & \\
\hline & MeJA2 & 0.56 & $0.84 \mathrm{a}$ & $0.64^{\mathrm{ns}}$ & $0.93 \mathrm{a}$ & $0.76 \mathrm{~b}$ & \\
\hline & & \multicolumn{5}{|c|}{ DPPH $(\mathrm{mmol} \mathrm{TE} \mathrm{kg-1})$} & \\
\hline & & Day 0 & Day 5 & Day 10 & Day 15 & Day 20 & \\
\hline \multirow{3}{*}{ With MAP } & Control & 2.83 & $4.88 \mathrm{c}$ & $5.58 \mathrm{c}$ & $4.71 \mathrm{~b}$ & $4.70 \mathrm{c}$ & \multirow{3}{*}{$5.24 \mathrm{a}$} \\
\hline & MeJA1 & 2.83 & $5.37 \mathrm{~b}$ & $6.40 \mathrm{~b}$ & $4.91 \mathrm{~b}$ & $6.29 \mathrm{~b}$ & \\
\hline & MeJA2 & 2.83 & $6.15 \mathrm{a}$ & $7.16 \mathrm{a}$ & $5.42 \mathrm{a}$ & $7.06 \mathrm{a}$ & \\
\hline \multirow{5}{*}{ Without MAP } & Control & 2.83 & $3.69 \mathrm{~b}$ & $2.94 \mathrm{c}$ & $4.48 \mathrm{~b}$ & $3.69 \mathrm{~b}$ & \multirow{3}{*}{$4.01 \mathrm{~b}$} \\
\hline & MeJA1 & 2.83 & $3.12 \mathrm{~b}$ & $3.43 \mathrm{~b}$ & $3.90 \mathrm{c}$ & $3.39 \mathrm{~b}$ & \\
\hline & MeJA2 & 2.83 & $4.91 \mathrm{a}$ & $3.70 \mathrm{a}$ & $5.16 \mathrm{a}$ & $5.65 \mathrm{a}$ & \\
\hline & & \multicolumn{5}{|c|}{ FRAP $\left(\mathrm{mmol} \mathrm{TE} \mathrm{kg}{ }^{-1}\right)$} & \\
\hline & & Day 0 & Day 5 & Day 10 & Day 15 & Day 20 & \\
\hline \multirow{3}{*}{ With MAP } & Control & 9.66 & $14.0 \mathrm{c}$ & $16.8 \mathrm{~b}$ & $13.4 \mathrm{~b}$ & $15.0 \mathrm{c}$ & \multirow{3}{*}{$15.6 \mathrm{a}$} \\
\hline & MeJA1 & 9.66 & $14.8 \mathrm{~b}$ & $17.3 \mathrm{a}$ & $14.6 \mathrm{a}$ & $16.0 \mathrm{~b}$ & \\
\hline & MeJA2 & 9.66 & $15.9 \mathrm{a}$ & $17.3 \mathrm{a}$ & $15.1 \mathrm{a}$ & $17.2 \mathrm{a}$ & \\
\hline \multirow{3}{*}{ Without MAP } & Control & 9.66 & $10.5 \mathrm{~b}$ & $10.5 \mathrm{~b}$ & $13.5 \mathrm{~b}$ & $13.2 \mathrm{c}$ & \multirow{3}{*}{$12.7 \mathrm{~b}$} \\
\hline & MeJA1 & 9.66 & $10.1 \mathrm{~b}$ & $11.8 \mathrm{a}$ & $12.3 \mathrm{~b}$ & $14.0 \mathrm{~b}$ & \\
\hline & MeJA2 & 9.66 & $13.6 \mathrm{a}$ & $12.4 \mathrm{a}$ & $15.0 \mathrm{a}$ & $15.0 \mathrm{a}$ & \\
\hline
\end{tabular}

ns: non-significant. The differences between the means indicated with the same lower-case letters in the same column were not significant according to Tukey's test

\section{Discussion}

Weight loss results in shrivelling, thus loss of allure and taste. In the present study, MAP treatments retarded weight loss throughout the storage period. MAP suppresses respiration rate, retards ripening and preserves high moisture levels with the ambient in which the fruit were placed (Muftuoğlu et al. 2012). Thusly, MAP-treated fruit had lower respiration rates than the untreated fruit. Several studies also reported retarded weight loss with MAP treatments (Muftuoğlu et al. 2012; Peano et al. 2014; Selcuk \& Erkan 2015; Moradinezhad \& Jahani 2016; Aglar et al. 2017). However, effects of MeJA on weight loss varied whether the fruit were placed into MAP. MeJA-treated fruit had lower weight loss values than the controls when they were placed into MAP, but had greater values when they were stored without MAP. MeJA might have contributed to cellular integrity of the fruit in MAP (Gonzalez-Aguilar et al. 2001; Ezzat et al. 2017). Thus, lower weight loss was experienced in MAP-treated fruit. Contrarily, Ozturk et al. (2019) reported that MeJA treatments did not have any extra contributions to weight loss of medlar fruit stored in MAP. Such a difference was attributed to differences in fruit species and treatments doses. In the current study, MeJA treatments suppressed respiration rate values of apricot fruit. Similar findings were also reported by previous researchers (Cao et al. 2009; Ezzat et al. 2017; Ozturk et al. 2019).

Flesh softening generates significant quality losses in apricot fruit. Therefore, firmer fruits are preferred in markets. In the present study, flesh softening was retarded with both MAP and MeJA treatments. MeJA had similar effects on MAP-treated and untreated fruit. Previous researchers also reported that flesh softening was retarded with MAP (Muftuoğlu et al. 2012; Selcuk \& Erkan 2015) and MeJA (Rudell et al. 2005; Balbontin et al. 2018; Ozturk et al. 2019). MAP suppresses ethylene synthesis and retards ripening with low $\mathrm{O}_{2}$ and high $\mathrm{CO}_{2}$ concentration. It was reported that MeJA inhibited ethylene synthesis, thus reduced the activity of cell wall-hydrolyzing enzymes and retarded fruit softening (Ziosi et al. 2008). However, Kondo et al. (2001) reported that effects of MeJA on flesh softening were independent from ethylene. Contrarily, there are some other studies reporting insignificant effects of MeJA in maintenance of flesh firmness (Shafiq et al. 2011; Rehman et al. 2018). Differences in research findings were mostly attributed to differences in treatment times (preharvest or postharvest) and doses, fruit species and cultivars. 
Fruit colour is an important sensorial quality attribute for consumers. In the present study, MAP-treated fruit had lower L* and chroma, but greater hue angle values. Present findings complied with the results of the studies reporting greater hue angle values (Peano et al. 2014) and lower L* and chroma values (Muftuoğlu et al. 2012) for MAP-treated apricot fruit. Although MeJA+MAP-treated fruit had significantly greater $\mathrm{L}^{*}$ values, distinctive effects of MeJA treatments on colour parameters were not observed in this study. Contrarily, it was reported in some studies (Rudell et al. 2005; Saracoglu et al. 2017; Balbontin et al. 2018) that MeJA had positive effects on promotion of colour development. Lalel et al. (2003) reported that MeJA promoted chlorophyll degradation and carotenoid biosynthesis, thus contributed to promotion of colour development. Kondo (2005) also reported that effects of MeJA on colour development might vary based on respiratory pattern of fruit such as climacteric or not. Differences among findings of this study were probably resulted from the differences in studied species and cultivars, and treatment doses.

Today, while consumers prefer fruit rich in nutrients, vitamins and antioxidants, growers prefer to produce such fruits. However, the critical issue herein is postharvest prevention or minimization of losses in nutritional attributes of the fruit with appropriate methods or treatments. In the present study, SSC, vitamin C, total phenolics, total flavonoids and antioxidant capacity were better maintained with MAP treatments as compared to untreated fruit. Previous studies also reported better maintenance of bioactive compounds with MAP treatments (Serrano et al. 2005; Singh \& Rao 2005; Ozturk et al. 2019).

Several researchers used MeJA to maintain postharvest fruit quality (Cao et al. 2009; Ezzat et al. 2017; Garcia-Pastor et al. 2019; Ozturk et al. 2019). In present study, MeJA treatments significantly retarded the losses in vitamin C, total phenolics and antioxidant capacity (both DPPH and FRAP) of apricot fruit. Greater MeJA concentration (1.0 mmol L-1) was even found to be more effective in retarding losses in these parameters. Thusly, Rudell et al. (2005) reported that effects of MeJA might vary with the fruit species and cultivars, treatment times and doses. Phenolic compounds are natural compounds that make the greatest contribution to antioxidant capacity. The greater bioactive contents of MeJA-treated fruits were attributed to stimulant effect of MeJA on defense mechanism and phenol synthesis (Ali et al. 2007).

\section{Conclusions}

It was concluded based on present findings that MAP and MeJA treatments could be used as an efficient tool to prevent or minimize the quality losses throughout the cold storage period. It was also concluded that MeJA yielded better outcomes when combined with MAP. Further detailed research is recommended to be conducted for the best application time of MeJA (preharvest or postharvest) and method of application (spraying or dipping) for better maintenance of quality attributes of apricot fruit.

\section{Acknowledgments}

The authors are grateful to Prof. Dr. Zeki Gokalp for his critical reading and through syntactic corrections of the manuscript. This research was supported by the Scientific Research Unit of Tokat Gaziosmanpaşa University with project number $2017 / 103$.

\section{References}

Aglar E, Ozturk B, Guler S K, Karakaya O, Uzun S \& Saracoglu O (2017). Effect of modified atmosphere packaging and 'Parka' treatments on fruit quality characteristics of sweet cherry fruits (Prunus avium L. '0900 Ziraat') during cold storage and shelf life. Scientia Horticulturae 222: 162-168. https://doi.org/10.1016/j.scienta.2017.05.024

Ali M B, Hahn E J \& Paek K Y (2007). Methyl jasmonate and salicylic acid induced oxidative stress and accumulation of phenols in Panax ginseng bioreactor root suspension cultures. Molecules 12: 607-621. https://doi.org/10.3390/12030607

Anonymous 2020. https://.tarimorman.gov.tr/BUGEM/ (Access to web: 08.10.2020)

Asma B M (2007). Malatya: world's capital of apricot culture. Chronica Horticulturae 47(1): 20-24

Balbontin C, Gutiérrez C, Wolff M \& Figueroa C R (2018). Effect of abscisic acid and methyl jasmonate preharvest applications on fruit quality and cracking tolerance of sweet cherry. Chilean Journal of Agricultural Research 78(3): 438-446. http://dx.doi.org/10.4067/S0718-58392018000300438

Benzie I F \& Strain J J (1996). The ferric reducing ability of plasma (FRAP) as a measure of "antioxidant power": the FRAP assay. Analytical Biochemistry 239: 70-76. https://doi.org/10.1006/abio.1996.0292

Beyhan Ö, Elmastaş M \& Gedikli F (2010). Total phenolic compounds and antioxidant capacity of leaf, dry fruit and fresh fruit of feijoa (Acca sellowiana, Myrtaceae). Journal of Medicinal Plants Research 4: 1065-1072

Blois M S (1958). Antioxidant determinations by the use of a stable free radical. Nature 26: 1199-1200

Cao S, Zheng Y, Yang Z, Wang K \& Rui H (2009). Effect of methyl jasmonate on quality and antioxidant activity of postharvest loquat fruit. Journal of the Science of Food and Agriculture 89: 2064-2070. https://doi.org/10.1002/jsfa.3691

Coşkun A L, Türkyılmaz M, Aksu Ö T, Koç B E, Yemiş O \& Özkan M (2013). Effects of various sulphuring methods and storage temperatures on the physical and chemical quality of dried apricots. Food Chemistry 141: 3670-3680. https://doi.org/10.1016/j.foodchem.2013.06.033

Dong L, Lurie S \& Zhou H W (2002). Effect of 1-methylcyclopropene on ripening of 'Canino' apricots and 'Royal Zee' plums. Postharvest Biology and Technology 24: 135-145. https://doi.org/10.1016/S0925-5214(01)00130-2 
Ezzat A, Ammar A, Szabo Z, Nyeki J \& Holb I J (2017). Postharvest treatments with methyl jasmonate and salicylic acid for maintaining physico-chemical characteristics and sensory quality properties of apricot fruit during cold storage and shelf-life. Polish Journal of Food and Nutrition Sciences 67: 159-166. https://doi.org/10.1515/pjfns-2016-0013

FAO 2020. http://www.fao.org/faostat/en/\#data (Access to web: 08.10.2020)

Garcia-Pastor M E, Serrano M, Guillen F, Castillo S, Martínez-Romero D, Valero D \& Zapata P J (2019). Methyl jasmonate effects on table grape ripening, vine yield, berry quality and bioactive compounds depend on applied concentration. Scientia Horticulturae 247: $380-389$. https://doi.org/10.1016/j.scienta.2018.12.043

Gonzalez-Aguilar G A, Buta J G \& Wang C Y (2001). Methyl jasmonate reduces chilling injury symptoms and enhances colour development of 'Kent' mangoes. Journal of the Science of Food and Agriculture 81: 1244-1249. https://doi.org/10.1002/jsfa.933

Jannatizadeh A, Naderi Boldaji M, Fatahi R, Ghasemi Varnamkhasti M \& Tabatabaeefar A (2008). Some postharvest physical properties of Iranian apricot [Prunus armeniaca L.] fruit. International Agrophysics 22(1): 125-131

Kondo S, Tsukada N, Niimi Y \& Seto H (2001). Interactions between jasmonates and abscisic acid in apple [Malus pumila] fruit, and stimulative effect of jasmonates on anthocyanin accumulation. Journal of the Japanese Society for Horticultural Science 70: 546-552. https://doi.org/10.2503/jjshs.70.546

Kondo S (2005). The roles of jasmonates in fruit color development and chilling injury. Acta Horticulturae 727: 45-56. https://doi.org/10.17660/ActaHortic.2006.727.3

Lalel H J D, Singh Z \& Tan S C (2003). The role of methyl jasmonate in mango ripening and biosynthesis of aroma volatile compounds. The Journal Horticultural Science and Biotechnology 78: 470-484. https://doi.org/10.1080/14620316.2003.11511652

Moradinezhad F \& Jahani M (2016). Quality improvement and shelf life extension of fresh apricot fruit (Prunus armeniaca cv. Shahroudi) using postharvest chemical treatments and packaging during cold storage. International Journal of Horticultural Science and Technology 3: 9-18. https://doi.org/10.22059/IJHST.2016.58156

Muftuoğlu F, Ayhan Z \& Esturk O (2012). Modified atmosphere packaging of Kabaaşı apricot (Prunus armeniaca L. 'Kabaaşı'): Effect of atmosphere, packaging material type and coating on the physicochemical properties and sensory quality. Food and Bioprocess Technology 5: 1601-1611. https://doi.org/10.1007/s11947-010-0482-6

Ozturk A, Yildiz K, Ozturk B, Karakaya O, Gun S, Uzun S \& Gundogdu M (2019). Maintaining postharvest quality of medlar (Mespilus germanica) fruit using modified atmosphere packaging and methyl jasmonate. LWT-Food Science and Technology 111: 117-124. https://doi.org/10.1016/j.lwt.2019.05.033

Peano C, Giuggioli N R \& Girgenti V (2014). Effects of innovative packaging materials on apricot fruits (cv Tom Cot@). Fruits 69: 247-258. https://doi.org/10.1051/fruits/2014014

Pretel M T, Souty M \& Romojaro F (2000). Use of passive and active modified atmosphere packaging to prolong the postharvest life of three varieties of apricot (Prunus armeniaca L.). European Food Research and Technology 211: 191-198. https://doi.org/10.1007/s002170050022

Rehman M, Singh Z \& Khurshid T (2018). Methyl jasmonate alleviates chilling injury and regulates fruit quality in 'Midknight' Valencia orange. Postharvest Biology and Technology 141: 58-62. https://doi.org/10.1016/j.postharvbio.2018.03.006

Rudell D R, Fellman J K \& Mattheis J P (2005). Preharvest application of methyl jasmonate to'Fuji' apples enhances red coloration and affects fruit size, splitting, and bitter pit incidence. Hortscience 40: 1760-1762. https://doi.org/10.21273/HORTSCI.40.6.1760

Saracoglu O, Ozturk B, Yildiz K \& Kucuker E (2017). Pre-harvest methyl jasmonate treatments delayed ripening and improved quality of sweet cherry fruits. Scientia Horticulturae 226: 19-23. https://doi.org/10.1016/j.scienta.2017.08.024

Selcuk N \& Erkan M (2015). The effects of modified and palliflex controlled atmosphere storage on postharvest quality and composition of 'Istanbul' medlar fruit. Postharvest Biology and Technology 99: 9-19. https://doi.org/10.1016/j.postharvbio.2014.07.004

Serrano M, Martinez-Romero D, Castillo S, Guillen F \& Valero D (2005). The use of natural antifungal compounds improves the beneficial effect of MAP in sweet cherry storage. Innovative Food Science and Emerging Technologies 6(1): 115-123. https://doi.org/10.1016/j.ifset.2004.09.001

Shafiq M, Singh Z \& Ahmad S K (2011). Pre-harvest spray administration of methyl jasmonate improves red blush and flavonoid content in 'Cripps Pink' apple. The Journal Horticultural Science and Biotechnology 86: 422-430. https://doi.org/10.1080/14620316.2011.11512784

Singh S P \& Rao D S (2005). Effect of modified atmosphere packaging (MAP) on the alleviation of chilling injury and dietary antioxidants levels in 'Solo' papaya during low temperature storage. European Journal of Horticultural Science 70: 246-252

Sochor J, Zitka O, Skutkova H, Pavlik D, Babula P, Krska B \& Kizek R (2010). Content of phenolic compounds and antioxidant capacity in fruits of apricot genotypes. Molecules 15: 6285-6305. https://doi.org/10.3390/molecules15096285

Yarılgaç T, Kadim H \& Ozturk B (2019). Role of maturity stages and modified atmosphere packaging on the quality attributes of cornelian cherry fruits (Cornus mas L.) throughout shelf life. Journal of the Science of Food and Agriculture 99: 421-428. https://doi.org/10.1002/jsfa.9203

Zhishen J, Mengcheng T \& Jianming W (1999). The determination of flavonoid contents in mulberry and their scavenging effects on superoxide radicals. Food Chemistry 64: 555-559. https://doi.org/10.1016/S0308-8146(98)00102-2

Ziosi V, Bonghi C, Bregoli A M, Trainotti L, Biondi S, Sutthiwal S \& Torrigiani P (2008). Jasmonate-induced transcriptional changes suggest a negative interference with the ripening syndrome in peach fruit. Journal of Experimental Botany 59: 563-573. https://doi.org/10.1093/jxb/erm331

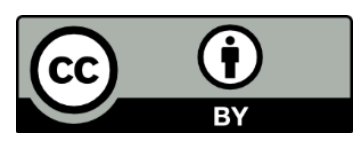

(C) 2022 by the author(s). Published by Ankara University, Faculty of Agriculture, Ankara, Turkey. This is an Open Access article distributed under the terms and conditions of the Creative Commons Attribution (CC BY) license (http://creativecommons.org/licenses/by/4.0/), which permits unrestricted use, distribution, and reproduction in any medium, provided the original work is properly cited. 